\title{
H2BW1 wt Allele
}

National Cancer Institute

\section{Source}

National Cancer Institute. H2BW1 wt Allele. NCI Thesaurus. Code C162842.

Human H2BW1 wild-type allele is located in the vicinity of Xq22.2 and is approximately 3 $\mathrm{kb}$ in length. This allele, which encodes histone H2B type W-T protein, may be involved in nucleosome formation and sperm maturation. 